\title{
Article
}

\section{MicroRNA-Target Interaction Regulatory Network in Alzheimer's Disease}

\author{
Aleksander Turk ${ }^{1}$, Tanja Kunej ${ }^{1, *}(\mathbb{D})$ and Borut Peterlin ${ }^{2, *}$ \\ 1 Department of Animal Science, Biotechnical Faculty, University of Ljubljana, 1230 Domžale, Slovenia; \\ turk.aleksander@gmail.com \\ 2 Clinical Institute of Genomic Medicine, University Medical Centre Ljubljana, 1000 Ljubljana, Slovenia \\ * Correspondence: tanja.kunej@bf.uni-lj.si (T.K.); borut.peterlin@kclj.si (B.P.)
}

check for

updates

Citation: Turk, A.; Kunej, T.; Peterlin, B. MicroRNA-Target Interaction Regulatory Network in Alzheimer's Disease. J. Pers. Med. 2021, 11, 1275. https://doi.org/10.3390/jpm11121275

Academic Editor: Valentina Bessi

Received: 30 September 2021

Accepted: 26 November 2021

Published: 2 December 2021

Publisher's Note: MDPI stays neutral with regard to jurisdictional claims in published maps and institutional affiliations.

Copyright: (c) 2021 by the authors. Licensee MDPI, Basel, Switzerland. This article is an open access article distributed under the terms and conditions of the Creative Commons Attribution (CC BY) license (https:// creativecommons.org/licenses/by/ $4.0 /)$.

\begin{abstract}
Alzheimer's Disease (AD) is a progressive neurodegenerative disorder and the most common cause of dementia; however, early diagnosis of the disease is challenging. Research suggests that biomarkers found in blood, such as microRNAs (miRNA), may be promising for AD diagnostics. Experimental data on miRNA-target interactions (MTI) associated with AD are scattered across databases and publications, thus making the identification of promising miRNA biomarkers for AD difficult. In response to this, a list of experimentally validated AD-associated MTIs was obtained from miRTarBase. Cytoscape was used to create a visual MTI network. STRING software was used for protein-protein interaction analysis and mirPath was used for pathway enrichment analysis. Several targets regulated by multiple miRNAs were identified, including: BACE1, APP, NCSTN, SP1, SIRT1, and PTEN. The miRNA with the highest numbers of interactions in the network were: miR-9, miR-16, miR-34a, miR-106a, miR-107, miR-125b, miR-146, and miR-181c. The analysis revealed seven subnetworks, representing disease modules which have a potential for further biomarker development. The obtained MTI network is not yet complete, and additional studies are needed for the comprehensive understanding of the AD-associated miRNA targetome.
\end{abstract}

Keywords: Alzheimer's disease; protein-protein interaction (PPI); biomarker; microRNA (miRNA); miRNA-target interaction (MTI)

\section{Introduction}

Alzheimer's disease (AD) is a complex, multifactorial, progressive neurodegenerative disorder afflicting the central nervous system (CNS) and is the most common cause of dementia. The disease's clinical progression is variable with several contributing factors, is irreversible and inevitably fatal [1]. The cause of the disease is mostly still unknown. It has been associated with the accumulation of misfolded amyloid beta $(A \beta)$ proteins, hyperphosphorylation of tau proteins, inflammation, the formation of neurofibrillary tangles, and single-nucleotide polymorphisms (SNPs) in certain AD-associated genes, such as the $A P O E$ gene [2]. $\mathrm{AD}$ is characterized by the loss of neurons and synapses in the brain, leading to a gradual loss of cognitive function. Disease progression is divided into three clinical stages: preclinical, prodromal, and dementia stages. In the disease's early stages, this manifests through episodes of forgetfulness, such as forgetting the names of family members and friends and confusion in unfamiliar situations. As the disease progresses, more regions of the brain are affected, resulting in severe difficulties with speech, thought, motor control, and other functions. Late-stage AD outcomes include irreversible disruptions to visual and visuospatial perception, behavioral alterations, losing one's ability to care for oneself, and progressively worsening cognitive and memory faculties. The formation of new memories becomes highly impaired, though older memories are often retained [1]. In 2015, it was estimated that 29.8 million people worldwide were living with $\mathrm{AD}[3]$. 
Diagnosing AD is often carried out by interviewing relatives about the person's overall health, medical history, drug use, and other relevant information. Cognitive tests can also be performed along with blood and urine tests. Brain scans may be used to rule out other causes of dementia; these include computed tomography (CT), magnetic resonance imaging (MRI), and positron emission tomography (PET) scans. Modern diagnostic methods are based on IWG-2 criteria, which rely on both biomarker and clinical phenotypes [4]. Despite these diagnostic methods, a definitive diagnosis can only be made after death with the examination of brain tissue. This is changing, however, as advancements in biomarker research are allowing more accurate assessment of the presence of AD. Three biomarkers have been established and examined in depth: A $\beta$ proteins, tau protein, and phosphorylated tau proteins. The current $\mathrm{AD}$ biomarker panel is categorized into three types of biomarker evidence for pathology, known together as the ATN classification system. This system allows individuals to be analyzed for three parameters: alterations of $A \beta$ proteins (in CSF or detected with PET scans; A), the hyperphosphorylation of tau proteins (in CSF or PET scans; T), and neurodegeneration levels (PET, MRI, and others; N) [5]. Accumulating evidence suggests that biomarkers found in blood (circulatory biomarkers) may be promising in identifying cases of AD. These include microRNAs (miRNAs), inflammatory markers, blood-based $A \beta$ markers, and biomarkers for oxidative stress [2].

In recent years, progress has been made in the field of biomarker development for AD. Analyzing A $\beta$ proteins in plasma together with other blood biomarkers can accurately detect cerebral $\mathrm{A} \beta$. This method yields even more accurate results when combined with APOE genotyping and thus reduces the cost of PET scans and need for lumbar punctures [6]. CSF and plasma p-tau181 and p-tau217 levels have also been studied as potential early biomarkers of AD [7]. These biomarkers were identified to be present in significantly higher concentrations in patients with early or mild AD. PET scans for tau proteins, on the other hand, presented more accurate results when gauging disease progression [8]. It has also been shown that plasma biomarkers, such as p-tau217, can be used to reduce the necessary sample size for future clinical trials [9]. Blood assay for p-tau181 has been identified as a promising biomarker for AD pathology. P-tau 181 has also been identified as a promising $\mathrm{AD}$ biomarker and has been shown to provide high diagnostic accuracy and the ability to differentiate AD from several other neurodegenerative diseases [10].

miRNAs are a class of short, non-coding RNA consisting of about 22 nucleotides. They play a role in the post-transcriptional regulation of gene expression as they, along with their associated proteins, bind to mRNA. This protein-miRNA complex then mediates either the degradation, destabilization, or repression of the mRNA. miRNA have been shown to have a wide array of targets, and one miRNA can target multiple mRNAs. It has also been shown that over $60 \%$ of protein-coding genes in humans have been under selective pressure to maintain sequences that would allow miRNA binding. Over 2000 human miRNA have so far been identified, and they are involved in numerous physiological processes as well as disease development [11-13].

Multiple miRNAs have thus far been associated with AD [2,14]. These miRNAs were identified as downregulated or upregulated in AD patients compared to healthy controls, and some have been shown to regulate AD-associated genes, such as APP and tau protein genes [14]. Plasma concentrations of miR-15b and miR-125b have been proposed as biomarkers of AD pathophysiology, and the study proposes a pathway-based approach to therapies for AD [15]. miRNA expression in AD is, similar to other contributing factors to the disease, highly heterogenous. A precision medicine approach to AD diagnostics has been proposed that includes: biomarker testing, and PET and MRI scans during the prodromal period of AD. This approach would allow more accurate disease trajectory predictions and treatment based on the individual patient's genetic, epigenetic, and neuroimaging profile [1]. miRNAs are also involved in both of the leading hypotheses for AD development-the amyloid cascade hypothesis and the tau hypothesis [16]. Nineteen miRNAs have been identified as having diagnostic potential in human AD studies. Among them, miR-206, miR-181a, and miR-146a from blood samples have shown the ability to 
predict whether mild cognitive impairment would progress to $\mathrm{AD}[17,18]$. Anti-miRNA (AM) treatments have also been proposed- using miRNA complementary strands of RNA. The AM approach has shown promise in murine models and cell cultures $[19,20]$. AM strategies for AD patients will likely require a more individual-focused approach to disease treatment, tailored to the individual's needs due to AD heterogeneity [21]. Potential therapeutic approaches are, however, not limited to AM strategies. Studies on cell cultures and animal models have also identified compounds that affect miRNA expression [22]. Current commonly used diagnostic methods are primarily based on CSF biomarkers. As circulatory miRNAs can be assessed in blood and do not require a lumbar puncture, their usage as biomarkers for diagnosis or potential treatment may be advantageous. While miRNAs may prove to be the preferable $\mathrm{AD}$ biomarker, data on their interactions with targets are fragmented, making it difficult for researchers to find a comprehensive overview of MTIs.

The aim of the present study was to: 1 . review published data on the currently known miRNAs associated with $\mathrm{AD}, 2$. present this information as the miRNA-target network to identify central molecules with potential for biomarker and therapeutic target development, and 3. conduct a pathway enrichment analysis and protein interaction analysis.

\section{Methods}

AD-associated miRNAs were retrieved from the online database miRTarBase, release 7.0 (http://mirtarbase.mbc.nctu.edu.tw/php/index.php) (accessed on 21 September 2021) [23]. The database contains experimentally validated MTIs. These MTIs were validated by using various methodologies, including reporter assay, Western blot, quantitative PCR (qPCR), microarrays, next-generation sequencing (NGS), and pSILAC. All data obtained from the database were manually reviewed. Each entry was also manually verified and only MTIs reported to be associated with $\mathrm{AD}$ were included in the analysis. The visual representation of the MTI network was made using the Cytoscape tool (https://cytoscape.org) (accessed on 24 September 2021) [24]. miRNA target genes were investigated for known protein-protein interactions (PPI) using the STRING database (https://string-db.org/) (accessed on 24 September 2021) [25]. AD-associated miRNAs were also analyzed for enrichment in biological pathways using mirPath v.3 (http:/ / diana.imis.athena-innovation. gr/DianaTools/index.php) (accessed on 2 November 2021) [26]. MirPath is a predictionbased bioinformatics tool that enables the identification of biological pathways in which the query miRNAs' target genes are enriched. The MirPath's KEGG analysis tool was utilized using the following parameters: $p$-value threshold of 0.05 and conservative estimates applied to the MicroT-CDS search algorithm. The obtained enriched biological pathways were manually reviewed for association with $\mathrm{AD}$ in previously published literature.

\section{Results}

A total of 37 unique miRNAs associated with AD were extracted from miRTarBase. The network consists of 37 miRNAs and 43 target genes, which are connected through 66 MTIs and experimentally validated by 45 unique articles. A list of MTIs is presented in Table 1 [27-71]. All MTIs presented in these results have been previously experimentally validated. The MTI network was visualized using Cytoscape software and is shown in Figure 1. miR-9, miR-107, miR-125b, and miR-146a were among miRNAs with the highest number of interactions, with four MTIs each. miR-16, miR-34a, miR-106a, and miR-181c were also highly connected, with three MTIs each. The most prominent miRNA targets were BACE1, APP, and NCSTN, which were the target of seven, seven, and four miRNAs, respectively. miRNAs and targets connected by multiple edges represent interactions confirmed by multiple independent experiments, such as the connections between BACE1 and hsa-miR-107. The results revealed a larger subnetwork consisting of 18 miRNA and 15 targets. Additionally, six smaller subnetworks of up to four MTIs were also identified. Twelve reported MTIs were between pairs of a single miRNA and target and were not part of a larger network. The targets of these 12 MTIs were: ATG5, BAX, BDNF, FKBP5, FOXO1, LRP1, MFN2, RARA, RCOR1, SNX6, SORL1, and UBE2A (Figure 1). The complete table of 
MTIs, which includes miRTarBase IDs and experimental validation methods for each MTI, is available in Supplementary Data (Supplementary Table S1).

Table 1. Experimentally validated MTIs associated with AD obtained from miRTarBase and literature [27-71].

\begin{tabular}{|c|c|c|c|}
\hline miRNA & Target Gene Symbol & Target Gene (Entrez Gene ID) & Reference (PMID) \\
\hline hsa-miR-20a-5p & $E 2 F 1$ & 1869 & 19110058 [39] \\
\hline hsa-miR-146a-5p & CFH & 3075 & $18801740[51]$ \\
\hline hsa-miR-106b-5p & $A P P$ & 351 & 19110058 [39] \\
\hline hsa-miR-101-3p & $A P P$ & 351 & 20395292 [59] \\
\hline hsa-miR-101-3p & $A P P$ & 351 & 21172309 [67] \\
\hline hsa-miR-29b-3p & $S P 1$ & 6667 & 23435408 [32] \\
\hline hsa-miR-146a-5p & IRAK1 & 3654 & $23952003[43]$ \\
\hline hsa-miR-107 & BACE1 & 23621 & 18234899 [57] \\
\hline hsa-miR-107 & BACE1 & 23621 & 20489155 [42] \\
\hline hsa-miR-29b-3p & BACE1 & 23621 & $18434550[60]$ \\
\hline hsa-miR-29b-3p & BACE1 & 23621 & $26818210[62]$ \\
\hline hsa-miR-146a-5p & ROCK1 & 6093 & $27221467[48]$ \\
\hline hsa-miR-205-5p & $L R P 1$ & 4035 & 19665999 [40] \\
\hline hsa-miR-9-5p & $B A C E 1$ & 23621 & $18434550[60]$ \\
\hline hsa-miR-29a-3p & BACE1 & 23621 & $18434550[60]$ \\
\hline hsa-miR-520c-3p & $A P P$ & 351 & 18684319 [63] \\
\hline hsa-miR-106a-5p & $A P P$ & 351 & 19110058 [39] \\
\hline hsa-miR-106a-5p & $A P P$ & 351 & 18684319 [63] \\
\hline hsa-miR-34a-5p & $B C L 2$ & 596 & 19683563 [49] \\
\hline hsa-miR-20a-5p & $A P P$ & 351 & 19110058 [39] \\
\hline hsa-miR-17-5p & $A P P$ & 351 & 19110058 [39] \\
\hline hsa-miR-125b-5p & $C D K N 2 A$ & 1029 & 20347935 [50] \\
\hline hsa-miR-107 & GRN & 2896 & 20489155 [42] \\
\hline hsa-miR-125b-5p & PPP1CA & 5499 & 25001178 [34] \\
\hline hsa-miR-34a-5p & SYT1 & 6857 & 22160687 [54] \\
\hline hsa-miR-34a-5p & STX1A & 6804 & 22160687 [54] \\
\hline hsa-miR-29a-3p & NAV3 & 89795 & $20202123[27]$ \\
\hline hsa-miR-375 & SP1 & 6667 & 23435408 [32] \\
\hline hsa-miR-181c-5p & TRIM2 & 23321 & 21720722 [37] \\
\hline hsa-miR-181c-5p & SIRT1 & 23411 & 21720722 [37] \\
\hline hsa-miR-9-5p & SIRT1 & 23411 & 21720722 [37] \\
\hline hsa-miR-9-5p & TGFBI & 7045 & 21720722 [37] \\
\hline hsa-miR-181c-5p & BTBD3 & 22903 & 21720722 [37] \\
\hline hsa-miR-22-3p & RCOR1 & 23186 & 23349832 [47] \\
\hline hsa-miR-29c-3p & $B A C E 1$ & 23621 & $21565331[70]$ \\
\hline hsa-miR-29c-3p & $B A C E 1$ & 23621 & 25973041 [29] \\
\hline hsa-miR-16-5p & $A P P$ & 351 & $26440600[46]$ \\
\hline hsa-miR-138-5p & $R A R A$ & 5914 & 25680531 [64] \\
\hline
\end{tabular}


Table 1. Cont.

\begin{tabular}{|c|c|c|c|}
\hline miRNA & Target Gene Symbol & Target Gene (Entrez Gene ID) & Reference (PMID) \\
\hline hsa-miR-125b-5p & $B C L 2 L 2$ & 599 & $25001178[34]$ \\
\hline hsa-miR-106a-5p & STAT3 & 6774 & $23399684[31]$ \\
\hline hsa-miR-132-5p & FOXO1 & 2308 & $24014289[53]$ \\
\hline hsa-miR-96-5p & SLC1A1 & 6505 & $24304186[56]$ \\
\hline hsa-miR-96-5p & SLC6A6 & 6533 & $24304186[56]$ \\
\hline hsa-miR-195-3p & MFN2 & 9927 & $27693395[71]$ \\
\hline hsa-miR-26b-5p & $R B 1$ & 5925 & $24027266[33]$ \\
\hline hsa-miR-339-5p & $B A C E 1$ & 23621 & $24352696[69]$ \\
\hline hsa-miR-214-3p & $B A X$ & 581 & $23408966[35]$ \\
\hline hsa-miR-455-5p & NCSTN & 23385 & $25100943[30]$ \\
\hline hsa-miR-186-5p & NCSTN & 23385 & $25100943[30]$ \\
\hline hsa-miR-24-3p & NCSTN & 23385 & $25100943[30]$ \\
\hline hsa-miR-125b-5p & DUSP6 & 1848 & $25001178[34]$ \\
\hline hsa-miR-107 & SH3GL2 & 6456 & $27038654[65]$ \\
\hline hsa-miR-511-5p & FKBP5 & 2289 & 27334923 [66] \\
\hline hsa-miR-299-5p & ATG5 & 9474 & 27080144 [52] \\
\hline hsa-miR-98-5p & SNX6 & 58533 & 27541017 [28] \\
\hline hsa-miR-16-5p & BACE1 & 23621 & 26440600 [46] \\
\hline hsa-miR-16-5p & NCSTN & 23385 & $26440600[46]$ \\
\hline hsa-miR-106b-5p & $F Y N$ & 2534 & 27520374 [58] \\
\hline hsa-miR-26b-5p & IGF1 & 3479 & 26847596 [55] \\
\hline hsa-miR-302a-3p & PTEN & 5728 & 26890744 [41] \\
\hline hsa-miR-9-5p & CAMKK2 & 10645 & 27394443 [45] \\
\hline hsa-miR-200c-3p & PTEN & 5728 & 28008308 [68] \\
\hline hsa-miR-146a-5p & $L R P 2$ & 4036 & 27241555 [38] \\
\hline hsa-miR-7-5p & $U B E 2 A$ & 7319 & 27929395 [61] \\
\hline hsa-miR-613 & $B D N F$ & 627 & 27545218 [44] \\
\hline hsa-miR-1229-3p & SORL1 & 6653 & $27328823[36]$ \\
\hline
\end{tabular}

Legend: $A P P$ : amyloid beta precursor protein, $A T G 5$ : autophagy related 5, BACE1: beta-secretase 1, BAX: BCL2 associated $\mathrm{X}$, apoptosis regulator, $B C L 2$ : $B C L 2$ apoptosis regulator, $B C L 2 L 2$ : BCL2 like 2, BDNF: brain derived neurotrophic factor, $B T B D 3$ : BTB domain containing 3, CAMKK2: calcium/calmodulin dependent protein kinase 2, CDKN2A: cyclin dependent kinase inhibitor 2A, CFH: complement factor $\mathrm{H}$, DUSP6: dual specificity phosphatase 6, E2F1: E2F transcription factor 2, FKBP5: FKBP prolyl isomerase 5, FOXO1: forkhead box O1, FYN: FYN proto-oncogene, Src family tyrosine kinase, GRN: granulin precursor. IGF1: insulin like growth factor 1. IRAK1: interleukin 1 receptor associated kinase 1. LRP1: LDL receptor related protein 1, LRP2: LDL receptor related protein 2, MFN2: mitofusin 2, NAV3: neuron navigator 3, NCSTN: nicastrin, PPP1CA: protein phosphatase 1 catalytic subunit alpha, PTEN: phosphatase and tensin homolog, RARA: retinoic acid receptor alpha, RB1: RB transcriptional corepressor 1, RCOR1: REST corepressor 1, ROCK1: Rho associated coiled-coil containing protein kinase 1, SH3GL2: SH3 domain containing GRB2 like 2, endophilin A1, SIRT1: sirtuin 1, SLC1A1: solute carrier family 1 member 1, SLC6A6: solute carrier family 6 member 6, SNX6: sorting nexin 6 , SORL1: sortilin related receptor 1, SP1: Sp1 transcription factor, STAT3: signal transducer and activator of transcription 3, STX1A; syntaxin 1A, SYT1: synaptotagmin 1, TGFBI: transforming growth factor beta induced, TRIM2: tripartite motif containing 2, UBE2A: ubiquitin conjugating enzyme E2 A. 


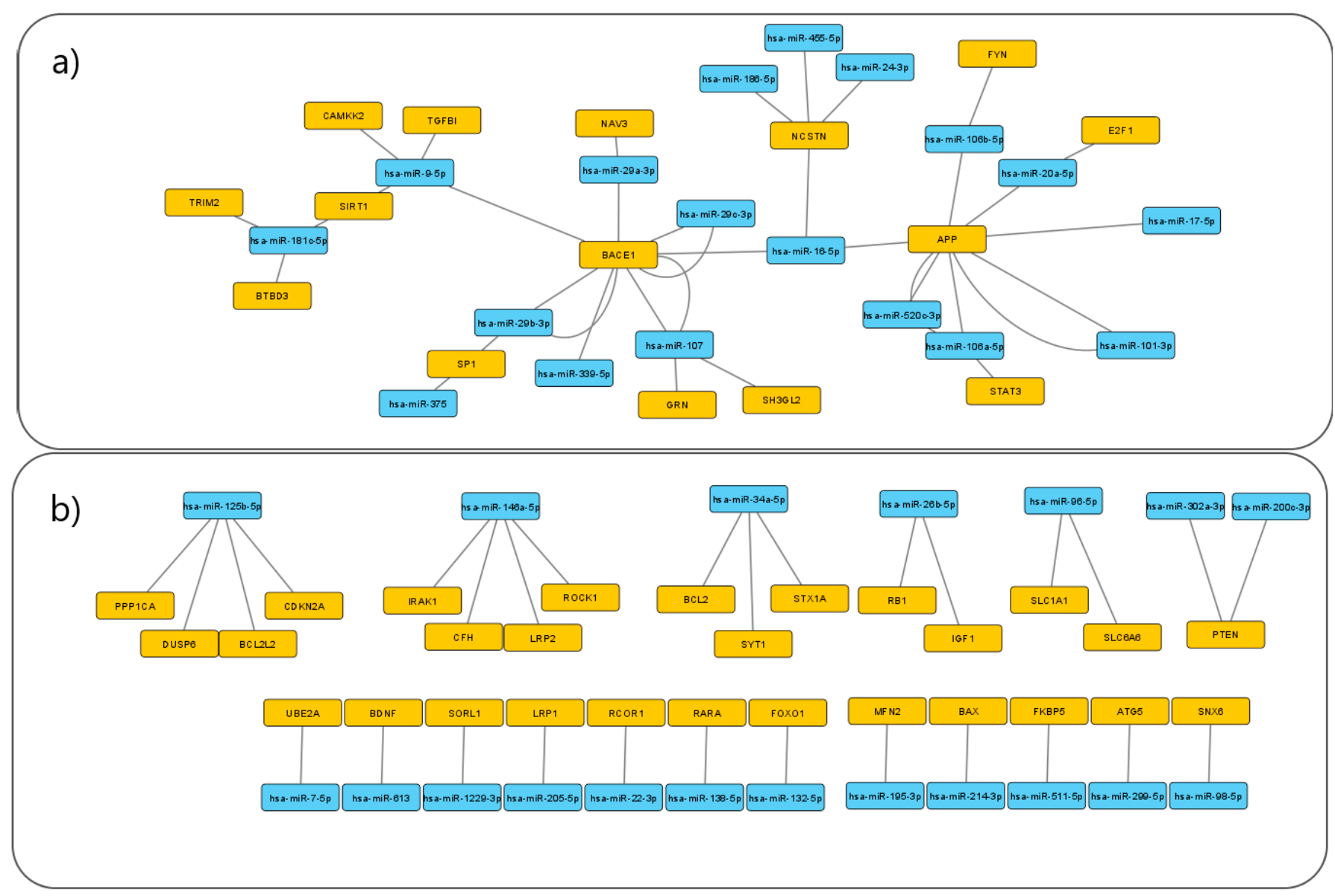

Figure 1. Network of experimentally validated MTIs associated with AD visualized using the Cytoscape software. Orangecolored nodes represent target genes while blue-colored nodes represent miRNAs. Each edge represents an experimentally validated interaction between a miRNA and its target. (a) The largest subnetwork identified in the data set, consisting of 18 miRNAs and 15 target genes, with a total of 37 MTIs. (b) Smaller subnetworks and miRNA-target pairs identified in the data set.

Target genes $(n=43)$ were then explored for PPIs using the STRING tool (Figure 2). A total of 41 of the 43 targets were part of a large PPI network; only two targets, UBE2A and $\mathrm{CFH}$, had no known interactions with the rest of the proteins in the network. The network includes 43 nodes with 110 interactions, which is significantly more interactions than expected (PPI enrichment $p$-value: $<1.0^{-16}$ ). Some proteins had notably more interactions than others, representing hubs. The five proteins with the most PPIs were: PTEN, SIRT1, APP, STAT3, BACE1, with 19, 16, 16, 9, and 7 PPIs, respectively. These five proteins are therefore present in 67 of the 110 PPIs in the network, thus representing central hub proteins.

To identify pathways in which $37 \mathrm{AD}$-associated miRNAs were enriched, we conducted an analysis with the mirPath tool. The analysis conducted using mirPath identified enrichments of the 37 unique AD-associated miRNAs in 68 biological pathways. Biological pathways were manually reviewed for association with AD based on literature. A total of 44 of the 68 biological pathways were associated with $\mathrm{AD}$ in previously published literature (Table 2) [69-112]. Thus, a total of 87 articles were reviewed for MTIs and enriched biological pathways. Supplementary Data (Supplementary Table S2) includes the full results of the pathway enrichment analysis. 


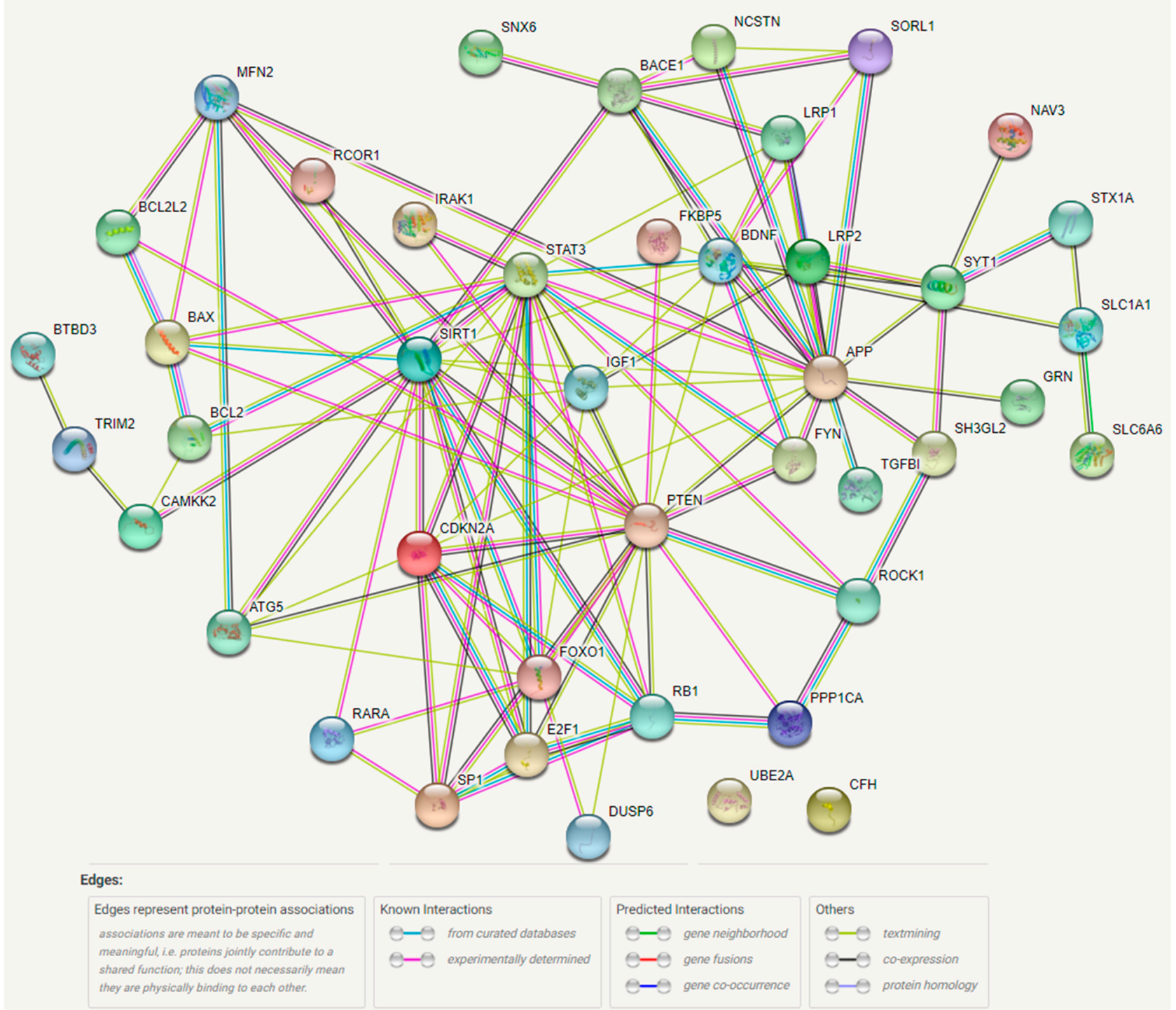

Figure 2. Protein-protein interaction network of 43 AD-associated miRNA targets using STRING software. The colors of connections between nodes represent the type interaction between the two proteins. The most reliable of these connections are "known interactions" from curated databases and experiments. Common gene neighborhoods, fusions, and cooccurrences as well as textmining, co-expression, and protein homology are considered less reliable connections and tend to require independent verification.

Table 2. Results of the pathway enrichment analysis using mirPath tool. The table includes pathways associated with AD in previously published literature. A total of $37 \mathrm{AD}$-associated miRNAs were enriched in 68 pathways. This table includes 44 pathways, which were associated with AD in previously published literature. The PMID (Reference) column includes references to publications associating the KEGG pathway with AD [72-115].

\begin{tabular}{|c|c|c|c|c|}
\hline KEGG Pathway & $p$-Value & $\begin{array}{c}\text { Number of } \\
\text { Genes }\end{array}$ & $\begin{array}{c}\text { Number of } \\
\text { miRNAs }\end{array}$ & $\begin{array}{c}\text { PMID } \\
\text { (Reference) }\end{array}$ \\
\hline Axon guidance & $2.03 \times 10^{-8}$ & 94 & 35 & 33675023 [103] \\
\hline Glioma & $2.38 \times 10^{-8}$ & 51 & 36 & $30560246[75]$ \\
\hline ErbB signaling pathway & $3.03 \times 10^{-8}$ & 71 & 37 & 21829755 [96] \\
\hline Adherens junction & $3.23 \times 10^{-8}$ & 61 & 35 & $27141420[78]$ \\
\hline
\end{tabular}


Table 2. Cont.

\begin{tabular}{|c|c|c|c|c|}
\hline KEGG Pathway & $p$-Value & $\begin{array}{l}\text { Number of } \\
\text { Genes }\end{array}$ & $\begin{array}{l}\text { Number of } \\
\text { miRNAs }\end{array}$ & $\begin{array}{c}\text { PMID } \\
\text { (Reference) }\end{array}$ \\
\hline Hippo signaling pathway & $5.39 \times 10^{-8}$ & 110 & 34 & 32232042 [113] \\
\hline Endocytosis & $4.19 \times 10^{-7}$ & 142 & 37 & 15639316 [108] \\
\hline TGF-beta signaling pathway & $1.05 \times 10^{-6}$ & 57 & 33 & $26578886[100]$ \\
\hline Rap1 signaling pathway & $3.20 \times 10^{-6}$ & 143 & 36 & $12819788[115]$ \\
\hline Focal adhesion & $9.32 \times 10^{-6}$ & 141 & 37 & $17215111[81]$ \\
\hline Neurotrophin signaling pathway & $1.16 \times 10^{-5}$ & 88 & 36 & 22654716 [99] \\
\hline PI3K-Akt signaling pathway & $1.45 \times 10^{-5}$ & 216 & 37 & 33258115 [97] \\
\hline ECM-receptor interaction & $1.93 \times 10^{-5}$ & 54 & 33 & $25410365[79]$ \\
\hline Ras signaling pathway & $1.93 \times 10^{-5}$ & 142 & 36 & 28374012 [106] \\
\hline Phosphatidylinositol signaling system & $2.28 \times 10^{-5}$ & 59 & 35 & 28847278 [77] \\
\hline Adrenergic signaling in cardiomyocytes & $2.28 \times 10^{-5}$ & 97 & 36 & 24001898 [85] \\
\hline Acute myeloid leukemia & $2.53 \times 10^{-5}$ & 45 & 37 & 25762156 [93] \\
\hline Mucin type O-Glycan biosynthesis & $2.54 \times 10^{-5}$ & 20 & 26 & $33218200[89]$ \\
\hline MAPK signaling pathway & $2.54 \times 10^{-5}$ & 168 & 37 & 12566928 [90] \\
\hline Estrogen signaling pathway & $6.29 \times 10^{-5}$ & 67 & 36 & 32297302 [101] \\
\hline Regulation of actin cytoskeleton & $8.73 \times 10^{-5}$ & 141 & 37 & $21276817[76]$ \\
\hline Wnt signaling pathway & 0.000213 & 96 & 33 & $31191253[91]$ \\
\hline AMPK signaling pathway & 0.000262 & 86 & 35 & $30776001[110]$ \\
\hline Colorectal cancer & 0.000271 & 47 & 34 & $30323761[80]$ \\
\hline mTOR signaling pathway & 0.000283 & 47 & 37 & $22202101[94]$ \\
\hline Oxytocin signaling pathway & 0.000283 & 103 & 37 & 30990880 [92] \\
\hline Prolactin signaling pathway & 0.000645 & 49 & 37 & 34126620 [109] \\
\hline FoxO signaling pathway & 0.001453 & 90 & 36 & $29149835[83]$ \\
\hline Hepatitis B & 0.001453 & 90 & 36 & 34398003 [102] \\
\hline cGMP-PKG signaling pathway & 0.001614 & 108 & 36 & 32715279 [111] \\
\hline Tight junction & 0.00311 & 87 & 36 & $30770921[104]$ \\
\hline Long-term potentiation & 0.004575 & 48 & 34 & 27377368 [107] \\
\hline Sphingolipid signaling pathway & 0.006623 & 75 & 36 & 20571935 [88] \\
\hline T cell receptor signaling pathway & 0.006678 & 69 & 36 & $23534386[98]$ \\
\hline Insulin signaling pathway & 0.008818 & 90 & 37 & 31275108 [112] \\
\hline Protein processing in endoplasmic reticulum & 0.009068 & 102 & 35 & 24832819 [87] \\
\hline Gap junction & 0.012445 & 58 & 35 & 33117125 [95] \\
\hline Inositol phosphate metabolism & 0.016986 & 42 & 32 & $15746379[72]$ \\
\hline Inflammatory mediator regulation of TRP channels & 0.018347 & 64 & 33 & 32351395 [105] \\
\hline Platelet activation & 0.018347 & 80 & 36 & $9561982[86]$ \\
\hline Glycosaminoglycan biosynthesis-heparan sulfate/heparin & 0.02388 & 16 & 24 & $25157361[74]$ \\
\hline cAMP signaling pathway & 0.024452 & 121 & 36 & $10556645[84]$ \\
\hline Type II diabetes mellitus & 0.031105 & 33 & 34 & $24526623[82]$ \\
\hline p53 signaling pathway & 0.03515 & 46 & 35 & $22042001[73]$ \\
\hline Fc gamma R-mediated phagocytosis & 0.040459 & 59 & 36 & 31901293 [114] \\
\hline
\end{tabular}




\section{Discussion}

In the present study, we formed an MTI network based on data on AD-associated miRNA, extracted from miRTarBase. This network contained seven MTI subnetworks and 12 MTI pairs. Nodes in the network with the highest number of edges include APP, BACE1, NCSTN, SIRT, and SP1, as well as the following miRNAs: miR-9, miR-16, miR-34a, miR106a, miR-107, miR-125b, miR-146, and miR-181c. We also investigated the miRNA targets for their interactions with other proteins, and visualized a PPI network, using STRING software. Furthermore, we conducted an enrichment analysis for AD-associated miRNAs.

Previously published literature indicates that miRNAs are an important regulatory mechanism for AD-associated gene expression [14]. So far, several miRNAs have been shown to regulate AD-associated genes [14]. As the main miRNA mechanism of action is the downregulation of target genes, it is important to assess whether they are being overor under-expressed in patients. Additionally, miRNA expression can be tissue-specific or bound to a specific mechanism, such as the regulation of extracellular vesicles, which are involved in cell communication [116]. As the understanding of the AD genetic background is not yet complete, observing miRNAs as a contributing factor may prove valuable.

The methods used for the validation of miRNA-target interactions are not all equally reliable and have different validation statuses. The miRTarBase methods are divided into strong and less strong based on the validation status. Methods such as Western blot, qPCR, and reporter assay are considered to give more reliable information and are marked as methods with strong validation status. Microarrays, NGS, pSILAC, and other methods are, by contrast, considered to generate less strong evidence. Consensus on the validation strength of methods has not yet been achieved as studies use different definitions of what constitutes strong and less strong evidence when it comes to MTIs. The edges between targets and miRNAs in Figure 1 do not distinguish between strong and less strong validation. In the future, these data could be accounted for in the graphical network.

The study results identified MTI subnetworks of varying sizes. The largest MTI subnetwork identified consists of 18 miRNAs and 15 target genes. The most prominent miRNA targets in the MTI network are APP, BACE1, NCSTN, SIRT, and SP1 as they are the targets of multiple miRNAs. The six smaller networks are composed of three to five nodes with two to four MTIs. In one subnetwork, two miRNAs regulate the same gene; where hsamiR-302a-3p and hsa-miR-200c-3p both target PTEN. From Figure 1, it is also apparent that there are 12 MTI pairs not connected to the other subnetworks.

As previously mentioned, five genes had the largest number of edges in the MTI network. Among these is the BACE1 gene, regulated by seven AD-associated miRNAs in the MTI network. Beta-secretase 1 is a protease encoded by the $B A C E 1$ gene. Its main role is the extracellular cleavage of the amyloid precursor protein (APP). It cleaves APP into two components, one of which is known as C99. This component is then further cleaved by $\gamma$-secretase, releasing an amyloid beta peptide $(\mathrm{A} \beta)$, which is the primary component in amyloid plaques. These plaques are commonly found in the brains of AD patients. Due to the correlation of amyloid plaque formation and $\mathrm{AD}, \mathrm{BACE1}$ has been closely studied. Inhibiting $B A C E 1$ would prevent the formation of $A \beta$, and it has been speculated that $B A C E 1$ inhibitors may prevent the development of the disease [117].

Another miRNA target with multiple MTIs is APP. Like BACE1, APP is also regulated by seven miRNAs in the MTI network. As seen in Figure 1, BACE1 and APP are both targeted by miR-16. As previously mentioned, APP is cleaved by proteases and is the precursor for $A \beta$. Despite being of great interest in connection to $A D$, its function is not completely known. Evidence shows that increased APP expression could promote the production of $A \beta$, leading to a negative impact on neurons and synapses [118].

Nicastrin is a protein encoded by the NCSTN gene. NCSTN is targeted by four miRNAs in the MTI network, making it the gene with the third-highest number of interactions with AD-associated miRNA. It is part of the $\gamma$-secretase protein complex and is thus connected to the formation of $A \beta$. No solid evidence has so far been found that would connect it to the development of $\mathrm{AD}$, though this does not exclude it as a potential contributing 
factor [119]. As seen in Figure 1, miR-16 regulates three highly interconnected genes in the MTI network-APP, BACE1, and NCSTN.

The SIRT1 gene encodes the enzyme NAD-dependent protein deacetylase sirtuin-1 (SIRT1). In the MTI network, SIRT1 is a target for two miRNAs: miR-181c and miR-9.

The roles and functions of human sirtuins are still largely unknown; however, SIRT1 has a known interaction with hypoxia-inducible factors $1 \alpha$ and $2 \alpha$ (HIF1A and EPAS1, respectively). HIF-1 $\alpha$ and EPAS1 are important for proper brain development as they are crucial for cell adaptation to hypoxia [120]. In murine models, all gene expression alterations in EPAS1-deficient mice have previously been associated with AD and memory loss [121]. SIRT1 was found to deacetylate the tau protein in some cell cultures. Among other interactions, it was also observed that it has a protective role in microglia-dependent A $\beta$ toxicity [122].

SP1 is a transcription factor and is targeted by two miRNAs in the MTI network: miR-29b and miR-375. SP1 may be involved in the development of AD as it can regulate the expression of several genes previously associated with AD, such as APP and tau protein genes. SP1 has also been shown to be significantly upregulated in the frontal cortex of AD patients [123].

PTEN is a gene that translates into the phosphatase and tensin homolog (PTEN) protein. PTEN is a target of miR-200c and miR-302a in the MTI network. Mutations in this gene are primarily associated with different types of cancer; however, they are also associated with AD through its role in synaptic and cognitive functions [124]. The gene also acts as a tumor suppressor, and its involvement with AD has been studied in mice [125].

Along with an MTI network, we also conducted a PPI analysis for AD-associated miRNA targets (Figure 2). Both the PPI and MTI network contained nodes with a large number of interactions, either with other targets (proteins) or miRNAs. The two networks share some nodes with multiple interactions. APP, BACE1, PTEN, SIRT1, and SP1 are targets that have the highest number of interactions in both networks. However, the PPI networks also include other highly connected proteins, such as STAT3, CDKN2A, E2F1, MFN2, RB1, and IGF1. The PPI network is highly interconnected: 41 of the 43 genes currently have at least one known or predicted interaction within the network. This level of interconnectedness of miRNA targets further points to the complex nature of AD.

A total of 37 AD-associated miRNAs were identified to be enriched in 68 biological pathways using the mirPath tool. For these 68 pathways, we conducted a secondary review of previously published literature and identified 44 pathways which have previously been described in association with AD. These 44 AD-associated pathways also include five pathways associated with other diseases: glioma, acute myeloid leukemia, colorectal cancer, hepatitis B, and type II diabetes mellitus. For example, glioma and AD share some common biological pathways associated with their development as well as genetic and environmental risk factors but are as of yet not causally related [75]. Common pathways with AD were also identified for acute myeloid leukemia [126] and colorectal cancer [80]. Interestingly, research has discovered an inverse correlation between AD risk and lung cancers [127] as well as other types of cancers [128-130]. Further studying the shared pathways between these diseases may yield additional insight into the role played by individual pathways in the development of AD.

Among the 44 AD-associated pathways, 39 pathways were not associated with diseases. These pathways are involved in inter- and intracellular signaling, gene regulation, cell adhesion, endocytosis, phagocytosis, and inflammation, which is expected, as these mechanisms have been shown to be involved in AD pathology [131]. The results of the analysis indicate that AD-associated miRNAs are involved in a variety of biological pathways. Based on the number and variety of pathways miRNA target genes are enriched in, miRNA appear to play a role in AD on multiple levels. Observing the disease at its endpoint, however, as is the tendency of study designs for AD-associated factors, has drawbacks. Due to the complexity of cellular regulatory mechanisms, observing dysregulations at the end point of a disease may not necessarily answer questions regarding its etiology. The 
interconnected nature of biological pathways means that the dysregulation of one pathway can cause the dysregulation of a second pathway. Though the second pathway is now dysregulated, studies observing the end-point of a disease's progression will not be able to discern between the cause and effect [132]. Therefore, longitudinal studies spanning from the preclinical stage of disease development to its endpoint are vital for the understanding of AD and consequently identifying therapeutic approaches.

MTIs acquired from miRTarBase do not include all genes whose variants are commonly associated with increased risk of AD. Their absence may be due to the incomplete initial data set, the current lack of knowledge about the role of miRNA in the contribution to AD development, or an indirect mechanism through which these risk variants contribute to the disease. Some genes commonly associated with AD, such as APOE, are currently not included in the database. $A P O E$ is considered one of the most influential genetic risk factors for late-onset AD—specifically, one of its three major isoforms, APOE-E4. The full extent of interactions between APOE and miRNA is not yet understood; however, it has been shown that levels of miR-1908 were negatively correlated with APOE expression [133]. Other known genetic AD risk factors include PSEN1 and PSEN2, specifically for early-onset AD [134]. PSEN1 is regulated by miR-193a [135] while PSEN2 knockout microglia cells exhibited the downregulation of miR-146 [43]. Further research into the involvement of $A P O E, P S E N 1$, and PSEN2 is required in order to acquire a better understanding of their role in AD. Future research is needed to reveal complete understanding of the role of miRNA in APOE, PSEN1, and PSEN2 regulation.

Different methods have been used both for the identification of novel biomarkers and for diagnostic purposes. For example, a cell culture reporter assay was used to determine that miR-107 regulates the expression of BACE1 [57]. Cell culture reporter assays, ELISA, xMap Luminex, shotgun proteomics, and other methods are commonly used to perform biomarker assays. The methodology on AD biomarker detection, however, is not entirely consistent among laboratories. For example, individual laboratories have different concentrations of $\mathrm{A} \beta$ that are considered low or high for the purpose of assays [136]. Blennow and Zetterberg (2018) have evaluated a large number of studies on miRNAs associated with AD and highlighted the need for a standardized analytical protocol among research centers [2]. A standardized approach for determining whether AD-associated molecules are present in low or high concentrations for the purpose of diagnostics is necessary for reliable, reproducible studies on AD.

Despite several important contributions to the development of the study field, there are also some limitations inherent to the present study. The study is limited by data available in the miRTarBase and mirPath databases, as these databases do not include all miRNAs and their targets currently known to be associated with AD. MirTarBase is one of the most extensive miRNA databases, but due to the rapid pace of the developments in this field, it may be challenging to keep a database up to date. Additionally, our initial dataset did not include expression levels and tissue specificity for miRNA and targets. The stage of AD during which measurements were taken was also not included, though these data could be taken into account in the future. The focus of the present study is the identification of interactions between known AD-associated miRNA and targets, their visualization, and the analysis of their enrichment in biological pathways. Through this, the study contribution is an overview of the interplay between miRNAs and AD-associated genes.

miRNAs have been extensively studied for their use as AD biomarkers in previously published literature [137]. A study by Lugli et al. (2015) assessing exosomal miRNAs as potential AD biomarkers has observed the differential presence of miRNAs in the plasma of AD patients. Twenty miRNAs showed notable differences, and seven of those were used for AD status prediction of patients using machine learning. The machine learning model predicted the patient's AD status based on samples with an 83-89\% accuracy; however, the authors recommend a replication with a larger cohort. The addition of miRNA expression data into other AD biomarker diagnostic tests is likely to further increase the diagnostic accuracy [138]. The results of a study by Leidinger et al. (2013) showed that a panel of 
12 blood-based miRNAs can be used to differentiate between AD patients and healthy controls with 93\% accuracy. This panel of 12 miRNAs can also differentiate between AD and other CNS disorders with 74-78\% accuracy [139]. Other studies testing circulatory miRNAs as biomarkers have also shown 75-95\% accuracies in identifying AD [140]. These studies are, however, focused on the late stages of AD. Integrating blood or plasma miRNA biomarkers with other biomarkers, such as $A \beta 40$ and $A \beta 42$, are likely prospective methods of early disease detection.

In the present study, miR-9, miR-16, miR-34a, miR-106a, miR-107, miR-125b, miR-146, and miR-181c were miRNAs present in the highest number of MTIs in the network. These miRNAs present promising components of regulation of AD-associated genes. miR-16 and miR-34a are involved in processes key to the amyloid cascade hypothesis model of AD development [14]. miR-16 inhibits APP expression while miR-34a inhibits the expression of proteins connected with $A \beta$ clearance [14]. miR-125b, meanwhile, is involved in the tau cascade hypothesis model, where its role is the inhibition of kinases responsible for tau hyperphosphorylation [14]. These miRNAs are differentially expressed in the brain and CSF; however, as diagnostic methods aim towards blood-based biomarkers, studies are necessary to elucidate whether they are also viable as circulatory biomarkers. Studies have shown the potential for blood-based miRNA biomarkers [137-140]. However, studies involving miRNA as circulatory biomarkers have, in the majority of cases, been performed with participants at the dementia stage of AD. Longitudinal studies with larger sample sizes are necessary to identify a combination of robust early detection biomarkers. As for therapeutic targets, research in the topic remains incomplete, being performed predominantly on cell cultures and murine models. Anti-miRNA (AM) approaches are challenged by an imperfect drug delivery system and unwanted effects on the expression of non-ADassociated genes, due to the multi-target nature of miRNAs. An anti-miR-146a (AM-146a) approach has shown a regained miRNA-associated homeostasis in murine models of AD. In cell cultures, AM-34a has returned overexpressed TREM2 [141] and SHANK3 [21] levels back to expected, normal levels, and thus, homeostasis. miRNAs as therapeutic targets should therefore not be ruled out, but more research is necessary to identify their level of potential for this purpose.

miRNAs play a prominent role in the regulation of AD-associated gene expression, with vast research potential into targets for screening, diagnosis, or treatment. Our analysis revealed seven subnetworks of MTIs, representing disease modules, which have the potential for network-based biomarker development. Further investigation into the cause of the upregulation or downregulation of miRNA may also prove useful in the search for the cause of AD. As there are a large number of miRNAs to consider in AD development, research, or screening, lab-on-a-chip technology is likely to be an efficient and cost-effective method to utilize.

\section{Conclusions}

In the present study, we conducted a synthesis of heterogenous results extracted from 88 unique studies; MTIs were obtained from 45 articles and AD-associated pathways from 43 articles. MTI data were visualized in the form of a network. A visual representation of experimentally validated MTIs has revealed potential novel network-based biomarkers. The miRNAs, their targets, MTIs, and associated biological pathways identified in this study hold potential for understanding AD progression. They also hold potential for additional circulatory biomarker development and therapeutic targets, as they are involved in multiple key molecules and mechanisms associated with AD. As research in the field grows, it is becoming more apparent that the role of miRNA in the development of AD is substantial and holds potential for the development of improved future diagnostics and therapeutic approaches. The results identified miRNAs and target genes representing central molecules, which will enable the formation of new hypotheses in the future. Research involving longitudinal studies and incorporating both miRNAs and other known biomarkers would 
allow the development of a more complete view of $\mathrm{AD}$ for advancements in disease screening, diagnosis, and treatment.

Supplementary Materials: The following are available online at https://www.mdpi.com/article/ 10.3390/jpm11121275/s1, Table S1: Complete table of MTI data, Table S2: Complete table of enriched KEGG pathways.

Author Contributions: A.T. drafted the paper, A.T. and T.K. designed the experiment, A.T. performed the database, literature screening, and data analysis. T.K. and B.P. verified the analytical methods. B.P. contributed to the clinical part of the text and revised the manuscript. All authors have read and agreed to the published version of the manuscript.

Funding: This research was funded by Slovenian Research Agency, research programs P3-0326 and P4-0220.

Institutional Review Board Statement: Not applicable.

Informed Consent Statement: Not applicable.

Data Availability Statement: For preparation of the manuscript, the publicly available database MiRTarBase was used (https:/ / mirtarbase.cuhk.edu.cn/ miRTarBase/miRTarBase_2019/php/index. php), accessed on 21 September 2021. Cytoscape version 3.7.2, an open source platform for network visualization was used (https: / / cytoscape.org) (accessed on 24 September 2021). STRING was used for protein-protein interaction analysis, accessed on 24 September 2021 (https://string-db.org/). mirPath v.3 was used for miRNA enrichment analysis, accessed on 2 November 2021 (http:/ / snf-5157 88.vm.okeanos.grnet.gr/). All the data are presented within the article and in supplementary material.

Conflicts of Interest: The authors declare no conflict of interest.

\section{References}

1. Zhao, Y.; Jaber, V.; Alexandrov, P.N.; Vergallo, A.; Lista, S.; Hampel, H.; Lukiw, W.J. microRNA-Based Biomarkers in Alzheimer's Disease (AD). Front. Neurosci. 2020, 14, 585432. [CrossRef] [PubMed]

2. Blennow, K.; Zetterberg, H. Biomarkers for Alzheimer's disease: Current status and prospects for the future. J. Intern. Med. 2018, 284, 643-663. [CrossRef] [PubMed]

3. Vos, T.; Allen, C.; Arora, M.; Barber, R.M.; Bhutta, Z.A.; Brown, A.; Carter, A.; Casey, D.C.; Charlson, F.J.; Chen, A.Z.; et al. GBD 2015 Disease and Injury Incidence and Prevalence Collaborators, Global, regional, and national incidence, prevalence, and years lived with disability for 310 diseases and injuries, 1990-2015: A systematic analysis for the Global Burden of Disease Study 2015. Lancet 2016, 388, 1545-1602. [CrossRef]

4. Dubois, B.; Feldman, H.; Jacova, C.; Hampel, H.; Molinuevo, J.L.; Blennow, K.; DeKosky, S.; Gauthier, S.; Selkoe, D.; Bateman, R.; et al. Advancing research diagnostic criteria for Alzheimer's disease: The IWG-2 criteria. Lancet Neurol. 2014, 13, 614-629. [CrossRef]

5. Jack, C.R., Jr.; Bennett, D.A.; Blennow, K.; Carrillo, M.C.; Dunn, B.; Haeberlein, S.B.; Holtzman, D.M.; Jagust, W.; Jessen, F.; Karlawish, J.; et al. NIA-AA Research Framework: Toward a biological definition of Alzheimer's disease. Alzheimer's Dement. 2018, 14, 535-562. [CrossRef] [PubMed]

6. $\quad$ Palmqvist, S.; Janelidze, S.; Stomrud, E.; Zetterberg, H.; Karl, J.; Zink, K.; Bittner, T.; Mattsson-Carlgren, N.; Eichenlaub, U.; Blennow, K.; et al. Performance of Fully Automated Plasma Assays as Screening Tests for Alzheimer Disease-Related $\beta$-Amyloid Status. JAMA Neurol. 2019, 76, 1060-1069. [CrossRef] [PubMed]

7. Brickman, A.M.; Manly, J.J.; Honig, L.S.; Sanchez, D.; Reyes-Dumeyer, D.; Lantigua, R.A.; Lao, P.J.; Stern, Y.; Vonsattel, J.P.; Teich, A.F.; et al. Plasma p-tau181, p-tau217, and other blood-based Alzheimer's disease biomarkers in a multi-ethnic, community study. Alzheimer's Dement. 2021, 17, 1353-1364. [CrossRef] [PubMed]

8. Ossenkoppele, R.; Reimand, J.; Smith, R.; Leuzy, A.; Strandberg, O.; Palmqvist, S.; Stomrud, E.; Zetterberg, H.; Scheltens, P.; Dage, J.L.; et al. Tau PET correlates with different Alzheimer's disease-related features compared to CSF and plasma p-tau biomarkers. EMBO Mol. Med. 2021, 13, e14398. [CrossRef]

9. Cullen, N.C.; Leuzy, A.; Janelidze, S.; Palmqvist, S.; Svenningsson, A.L.; Stomrud, E.; Dage, J.L.; Mattsson-Carlgren, N.; Hansson, O. Plasma biomarkers of Alzheimer's disease improve prediction of cognitive decline in cognitively unimpaired elderly populations. Nat. Commun. 2021, 12, 3555. [CrossRef] [PubMed]

10. Karikari, T.K.; Pascoal, T.A.; Ashton, N.J.; Janelidze, S.; Benedet, A.L.; Rodriguez, J.L.; Chamoun, M.; Savard, M.; Kang, M.S.; Therriault, J.; et al. Blood phosphorylated tau 181 as a biomarker for Alzheimer's disease: A diagnostic performance and prediction modelling study using data from four prospective cohorts. Lancet Neurol. 2020, 19, 422-433. [CrossRef]

11. Hrovatin, K.; Kunej, T. Classification of miRNA-related sequence variations. Epigenomics 2018, 10, 463-481. [CrossRef] [PubMed]

12. Friedman, R.; Farh, K.K.-H.; Burge, C.B.; Bartel, D.P. Most mammalian mRNAs are conserved targets of microRNAs. Genome Res. 2008, 19, 92-105. [CrossRef] [PubMed] 
13. Hammond, S.M. An overview of microRNAs. Adv. Drug Deliv. Rev. 2015, 87, 3-14. [CrossRef] [PubMed]

14. Wang, M.; Qin, L.; Tang, B. MicroRNAs in Alzheimer's Disease. Front. Genet. 2019, 10, 153. [CrossRef] [PubMed]

15. Vergallo, A.; Lista, S.; Zhao, Y.; Lemercier, P.; Teipel, S.J.; Potier, M.-C.; Habert, M.-O.; Dubois, B.; Lukiw, W.J.; Hampel, H.; et al. MiRNA-15b and miRNA-125b are associated with regional A $\beta$-PET and FDG-PET uptake in cognitively normal individuals with subjective memory complaints. Transl. Psychiatry 2021, 11, 78. [CrossRef] [PubMed]

16. Ballard, C.; Gauthier, S.; Corbett, A.; Brayne, C.; Aarsland, D.; Jones, E. Alzheimer's disease. Lancet 2011, 377, 1019-1031. [CrossRef]

17. Ansari, A.; Maffioletti, E.; Milanesi, E.; Marizzoni, M.; Frisoni, G.B.; Blin, O.; Richardson, J.C.; Bordet, R.; Forloni, G.; Gennarelli, M.; et al. miR-146a and miR-181a are involved in the progression of mild cognitive impairment to Alzheimer's disease. Neurobiol. Aging 2019, 82, 102-109. [CrossRef] [PubMed]

18. Xie, B.; Liu, Z.; Jiang, L.; Liu, W.; Song, M.; Zhang, Q.; Zhang, R.; Cui, D.; Wang, X.; Xu, S. Increased Serum miR-206 Level Predicts Conversion from Amnestic Mild Cognitive Impairment to Alzheimer's Disease: A 5-Year Follow-up Study. J. Alzheimer's Dis. 2016, 55, 509-520. [CrossRef]

19. Henry, R.; Doran, S.J.; Barrett, J.; Meadows, V.E.; Sabirzhanov, B.; Stoica, B.A.; Loane, D.J.; Faden, A.I. Inhibition of miR-155 Limits Neuroinflammation and Improves Functional Recovery After Experimental Traumatic Brain Injury in Mice. Neurotherapeutics 2018, 16, 216-230. [CrossRef]

20. Lukiw, W.J. NF-kB-regulated micro RNAs (miRNAs) in primary human brain cells. Exp. Neurol. 2012, 235, 484-490. [CrossRef] [PubMed]

21. Jaber, V.R.; Zhao, Y.; Sharfman, N.M.; Li, W.; Lukiw, W.J. Addressing Alzheimer's Disease (AD) Neuropathology Using AntimicroRNA (AM) Strategies. Mol. Neurobiol. 2019, 56, 8101-8108. [CrossRef]

22. Abuelezz, N.Z.; Nasr, F.E.; AbdulKader, M.A.; Bassiouny, A.R.; Zaky, A. MicroRNAs as Potential Orchestrators of Alzheimer's Disease-Related Pathologies: Insights on Current Status and Future Possibilities. Front. Aging Neurosci. 2021, 13, 743573. [CrossRef]

23. Chou, C.-H.; Shrestha, S.; Yang, C.-D.; Chang, N.-W.; Lin, Y.-L.; Liao, K.-W.; Huang, W.-C.; Sun, T.-H.; Tu, S.-J.; Lee, W.-H.; et al. miRTarBase update 2018: A resource for experimentally validated microRNA-target interactions. Nucleic Acids Res. 2017, 46, D296-D302. [CrossRef] [PubMed]

24. Shannon, P.; Markiel, A.; Ozier, O.; Baliga, N.S.; Wang, J.T.; Ramage, D.; Amin, N.; Schwikowski, B.; Ideker, T. Cytoscape: A Software Environment for Integrated Models of Biomolecular Interaction Networks. Genome Res. 2003, 13, 2498-2504. [CrossRef] [PubMed]

25. Szklarczyk, D.; Gable, A.L.; Nastou, K.C.; Lyon, D.; Kirsch, R.; Pyysalo, S.; Doncheva, N.T.; Legeay, M.; Fang, T.; Bork, P.; et al. The STRING database in 2021: Customizable protein-protein networks, and functional characterization of user-uploaded gene/measurement sets. Nucleic Acids Res. 2020, 49, D605-D612. [CrossRef] [PubMed]

26. Vlachos, I.S.; Zagganas, K.; Paraskevopoulou, M.D.; Georgakilas, G.; Karagkouni, D.; Vergoulis, T.; Dalamagas, T.; Hatzigeorgiou, A.G. DIANA-miRPath v3.0: Deciphering microRNA function with experimental support. Nucleic Acids Res. 2015, 43, W460-W466. [CrossRef]

27. Shioya, M.; Obayashi, S.; Tabunoki, H.; Arima, K.; Saito, Y.; Ishida, T.; Satoh, J. Aberrant microRNA expression in the brains of neurodegenerative diseases: miR-29a decreased in Alzheimer disease brains targets neurone navigator 3. Neuropathol. Appl. Neurobiol. 2010, 36, 320-330. [CrossRef] [PubMed]

28. Li, Q.; Li, X.; Wang, L.; Zhang, Y.; Chen, L. miR-98-5p Acts as a Target for Alzheimer's Disease by Regulating A $\beta$ Production Through Modulating SNX6 Expression. J. Mol. Neurosci. 2016, 60, 413-420. [CrossRef]

29. Lei, X.; Lei, L.; Zhang, Z.; Zhang, Z.; Cheng, Y. Downregulated miR-29c correlates with increased BACE1 expression in sporadic Alzheimer's disease. Int. J. Clin. Exp. Pathol. 2015, 8, 1565-1574. [PubMed]

30. Edelay, C.; Dorval, V.; Efok, A.; Egrenier-Boley, B.; Lambert, J.-C.; Hsiung, G.-Y.; Hébert, S.S. MicroRNAs targeting Nicastrin regulate $\mathrm{A} \beta$ production and are affected by target site polymorphisms. Front. Mol. Neurosci. 2014, 7, 67. [CrossRef]

31. Zhang, M.; Ye, Y.; Cong, J.; Pu, D.; Liu, J.; Hu, G.; Wu, J. Regulation of STAT3 by miR-106a is linked to cognitive impairment in ovariectomized mice. Brain Res. 2013, 1503, 43-52. [CrossRef] [PubMed]

32. Villa, C.; Ridolfi, E.; Fenoglio, C.; Ghezzi, L.; Vimercati, R.; Clerici, F.; Marcone, A.; Gallone, S.; Serpente, M.; Cantoni, C.; et al. Expression of the Transcription Factor Sp1 and its Regulatory hsa-miR-29b in Peripheral Blood Mononuclear Cells from Patients with Alzheimer's Disease. J. Alzheimer's Dis. 2013, 35, 487-494. [CrossRef] [PubMed]

33. Absalon, S.; Kochanek, D.M.; Raghavan, V.; Krichevsky, A.M. MiR-26b, Upregulated in Alzheimer's Disease, Activates Cell Cycle Entry, Tau-Phosphorylation, and Apoptosis in Postmitotic Neurons. J. Neurosci. 2013, 33, 14645-14659. [CrossRef] [PubMed]

34. Banzhaf-Strathmann, J.; Benito, E.; May, S.; Arzberger, T.; Tahirovic, S.; Kretzschmar, H.; Fischer, A.; Edbauer, D. Micro RNA-125b induces tau hyperphosphorylation and cognitive deficits in Alzheimer's disease. EMBO J. 2014, 33, 1667-1680. [CrossRef] [PubMed]

35. Yan, H.; Xu, T.; Zhao, H.; Lee, K.-C.; Wang, H.-Y.; Zhang, Y. Isoflurane Increases Neuronal Cell Death Vulnerability by Downregulating miR-214. PLoS ONE 2013, 8, e55276. [CrossRef] [PubMed]

36. Ghanbari, M.; Ikram, M.A.; De Looper, H.W.J.; Hofman, A.; Erkeland, S.J.; Franco, O.H.; Dehghan, A. Genome-wide identification of microRNA-related variants associated with risk of Alzheimer's disease. Sci. Rep. 2016, 6, 28387. [CrossRef] [PubMed]

37. Schonrock, N.; Humphreys, D.; Preiss, T.; Götz, J. Target Gene Repression Mediated by miRNAs miR-181c and miR-9 Both of Which Are Down-regulated by Amyloid- $\beta$. J. Mol. Neurosci. 2011, 46, 324-335. [CrossRef]

38. Zhang, B.; Wang, L.-L.; Ren, R.-J.; Dammer, E.; Zhang, Y.-F.; Huang, Y.; Chen, S.-D.; Wang, G. MicroRNA-146a represses LRP2 translation and leads to cell apoptosis in Alzheimer's disease. FEBS Lett. 2016, 590, 2190-2200. [CrossRef] 
39. Hebert, S.; Horré, K.; Nicolaï, L.; Bergmans, B.; Papadopoulou, A.S.; Delacourte, A.; De Strooper, B. MicroRNA regulation of Alzheimer's Amyloid precursor protein expression. Neurobiol. Dis. 2009, 33, 422-428. [CrossRef] [PubMed]

40. Song, H.; Bu, G. MicroRNA-205 inhibits tumor cell migration through down-regulating the expression of the LDL receptor-related protein 1. Biochem. Biophys. Res. Commun. 2009, 388, 400-405. [CrossRef]

41. Li, H.-H.; Lin, S.-L.; Huang, C.-N.; Lu, F.-J.; Chiu, P.-Y.; Huang, W.-N.; Lai, T.-J.; Lin, C.-L. miR-302 Attenuates Amyloid- $\beta$-Induced Neurotoxicity through Activation of Akt Signaling. J. Alzheimer's Dis. 2016, 50, 1083-1098. [CrossRef] [PubMed]

42. Wang, W.-X.; Wilfred, B.R.; Madathil, S.K.; Tang, G.; Hu, Y.; Dimayuga, J.; Stromberg, A.J.; Huang, Q.; Saatman, K.E.; Nelson, P.T. miR-107 Regulates Granulin/Progranulin with Implications for Traumatic Brain Injury and Neurodegenerative Disease. Am. J. Pathol. 2010, 177, 334-345. [CrossRef]

43. Jayadev, S.; Case, A.; Alajajian, B.; Eastman, A.J.; Möller, T.; Garden, G.A. Presenilin 2 influences miR146 level and activity in microglia. J. Neurochem. 2013, 127, 592-599. [CrossRef]

44. Li, W.; Li, X.; Xin, X.; Kan, P.-C.; Yan, Y. MicroRNA-613 regulates the expression of brain-derived neurotrophic factor in Alzheimer's disease. Biosci. Trends 2016, 10, 372-377. [CrossRef]

45. Li, S.; Yan, Y.; Jiao, Y.; Gao, Z.; Xia, Y.; Kong, L.; Yao, Y.; Tao, Z.; Song, J.; Yan, Y.; et al. Neuroprotective Effect of Osthole on Neuron Synapses in an Alzheimer's Disease Cell Model via Upregulation of MicroRNA-9. J. Mol. Neurosci. 2016, 60, 71-81. [CrossRef] [PubMed]

46. Parsi, S.; Smith, P.Y.; Goupil, C.; Dorval, V.; Hébert, S.S. Preclinical Evaluation of miR-15/107 Family Members as Multifactorial Drug Targets for Alzheimer's Disease. Mol. Ther. Nucleic Acids 2015, 4, e256. [CrossRef] [PubMed]

47. Jovicic, A.; Jolissaint, J.F.Z.; Moser, R.; Santos, M.D.F.S.S.; Luthi-Carter, R. MicroRNA-22 (miR-22) Overexpression Is Neuroprotective via General Anti-Apoptotic Effects and May also Target Specific Huntington's Disease-Related Mechanisms. PLoS ONE 2013, 8, e54222. [CrossRef]

48. Wang, G.; Huang, Y.; Wang, L.-L.; Zhang, Y.-F.; Xu, J.; Zhou, Y.; Lourenco, G.; Zhang, B.; Wang, Y.; Ren, R.-J.; et al. MicroRNA-146a suppresses ROCK1 allowing hyperphosphorylation of tau in Alzheimer's disease. Sci. Rep. 2016, 6, 26697. [CrossRef]

49. Wang, X.; Liu, P.; Zhu, H.; Xu, Y.; Ma, C.; Dai, X.; Huang, L.; Liu, Y.; Zhang, L.; Qin, C. miR-34a, a microRNA up-regulated in a double transgenic mouse model of Alzheimer's disease, inhibits bcl2 translation. Brain Res. Bull. 2009, 80, 268-273. [CrossRef]

50. Pogue, A.; Cui, J.; Li, Y.; Zhao, Y.; Culicchia, F.; Lukiw, W. Micro RNA-125b (miRNA-125b) function in astrogliosis and glial cell proliferation. Neurosci. Lett. 2010, 476, 18-22. [CrossRef]

51. Lukiw, W.J.; Zhao, Y.; Cui, J.G. An NF-kB-sensitive Micro RNA-146a-mediated Inflammatory Circuit in Alzheimer Disease and in Stressed Human Brain Cells. J. Biol. Chem. 2008, 283, 31315-31322. [CrossRef] [PubMed]

52. Zhang, Y.; Liu, C.; Wang, J.; Li, Q.; Ping, H.; Gao, S.; Wang, P. MiR-299-5p regulates apoptosis through autophagy in neurons and ameliorates cognitive capacity in APPswe/PS1dE9 mice. Sci. Rep. 2016, 6, 24566. [CrossRef] [PubMed]

53. Lau, P.; Bossers, K.; Janky, R.; Salta, E.; Frigerio, C.S.; Barbash, S.; Rothman, R.; Sierksma, A.S.R.; Thathiah, A.; Greenberg, D.; et al. Alteration of the micro RNA network during the progression of Alzheimer's disease. EMBO Mol. Med. 2013, 5, 1613-1634. [CrossRef] [PubMed]

54. Agostini, M.; Tucci, P.; Killick, R.; Candi, E.; Sayan, B.S.; Cervo, P.R.D.V.; Nicotera, P.; McKeon, F.; Knight, R.A.; Mak, T.W.; et al. Neuronal differentiation by TAp73 is mediated by microRNA-34a regulation of synaptic protein targets. Proc. Natl. Acad. Sci. USA 2011, 108, 21093-21098. [CrossRef]

55. Liu, H.; Chu, W.; Gong, L.; Gao, X.; Wang, W. MicroRNA-26b is upregulated in a double transgenic mouse model of Alzheimer's disease and promotes the expression of amyloid- $\beta$ by targeting insulin-like growth factor 1. Mol. Med. Rep. 2016, 13, $2809-2814$. [CrossRef]

56. Ubhi, K.; Rockenstein, E.; Kragh, C.; Inglis, C.; Spencer, B.; Michael, S.; Mante, M.; Adame, A.; Galasko, D.; Masliah, E. Widespread microRNA dysregulation in multiple system atrophy-disease-related alteration in miR-96. Eur. J. Neurosci. 2013, 39, $1026-1041$. [CrossRef]

57. Wang, W.-X.; Rajeev, B.W.; Stromberg, A.J.; Ren, N.; Tang, G.; Huang, Q.; Rigoutsos, I.; Nelson, P.T. The Expression of MicroRNA miR-107 Decreases Early in Alzheimer's Disease and May Accelerate Disease Progression through Regulation of $\beta$-Site Amyloid Precursor Protein-Cleaving Enzyme 1. J. Neurosci. 2008, 28, 1213-1223. [CrossRef]

58. Liu, W.; Zhao, J.; Lu, G. miR-106b inhibits tau phosphorylation at Tyr18 by targeting Fyn in a model of Alzheimer's disease. Biochem. Biophys. Res. Commun. 2016, 478, 852-857. [CrossRef]

59. Vilardo, E.; Barbato, C.; Ciotti, M.; Cogoni, C.; Ruberti, F. MicroRNA-101 Regulates Amyloid Precursor Protein Expression in Hippocampal Neurons. J. Biol. Chem. 2010, 285, 18344-18351. [CrossRef]

60. Hébert, S.; Horré, K.; Nicolaï, L.; Papadopoulou, A.S.; Mandemakers, W.; Silahtaroglu, A.; Kauppinen, S.; Delacourte, A.; De Strooper, B. Loss of microRNA cluster miR-29a/b-1 in sporadic Alzheimer's disease correlates with increased BACE1/ $\beta$ secretase expression. Proc. Natl. Acad. Sci. USA 2008, 105, 6415-6420. [CrossRef]

61. Zhao, Y.; Alexandrov, P.N.; Jaber, V.; Lukiw, W.J. Deficiency in the Ubiquitin Conjugating Enzyme UBE2A in Alzheimer's Disease (AD) is Linked to Deficits in a Natural Circular miRNA-7 Sponge (circRNA; ciRS-7). Genes 2016, 7, 116. [CrossRef] [PubMed]

62. Pereira, P.A.; Tomás, J.F.; Queiroz, J.A.; Figueiras, A.R.; Sousa, F. Recombinant pre-miR-29b for Alzheimer's disease therapeutics. Sci. Rep. 2016, 6, 19946. [CrossRef]

63. Patel, N.; Hoang, D.; Miller, N.; Ansaloni, S.; Huang, Q.; Rogers, J.T.; Lee, J.C.; Saunders, A.J. MicroRNAs can regulate human APP levels. Mol. Neurodegener. 2008, 3, 10. [CrossRef] [PubMed] 
64. Wang, X.; Tan, L.; Lu, Y.; Peng, J.; Zhu, Y.; Zhang, Y.; Sun, Z. MicroRNA-138 promotes tau phosphorylation by targeting retinoic acid receptor alpha. FEBS Lett. 2015, 589, 726-729. [CrossRef] [PubMed]

65. Liu, W.; Cai, H.; Lin, M.; Zhu, L.; Gao, L.; Zhong, R.; Bi, S.; Xue, Y.; Shang, X. MicroRNA-107 prevents amyloid-beta induced blood-brain barrier disruption and endothelial cell dysfunction by targeting Endophilin-1. Exp. Cell Res. 2016, 343, 248-257. [CrossRef] [PubMed]

66. Zheng, D.; Sabbagh, J.J.; Blair, L.; Darling, A.L.; Wen, X.; Dickey, C.A. MicroRNA-511 Binds to FKBP5 mRNA, Which Encodes a Chaperone Protein, and Regulates Neuronal Differentiation. J. Biol. Chem. 2016, 291, 17897-17906. [CrossRef]

67. Long, J.M.; Lahiri, D.K. MicroRNA-101 downregulates Alzheimer's amyloid- $\beta$ precursor protein levels in human cell cultures and is differentially expressed. Biochem. Biophys. Res. Commun. 2011, 404, 889-895. [CrossRef] [PubMed]

68. Wu, Q.; Ye, X.; Xiong, Y.; Zhu, H.; Miao, J.; Zhang, W.; Wan, J. The Protective Role of microRNA-200c in Alzheimer's Disease Pathologies Is Induced by Beta Amyloid-Triggered Endoplasmic Reticulum Stress. Front. Mol. Neurosci. 2016, 9, 140. [CrossRef] [PubMed]

69. Long, J.; Ray, B.; Lahiri, D.K. MicroRNA-339-5p Down-regulates Protein Expression of $\beta$-Site Amyloid Precursor Protein-Cleaving Enzyme 1 (BACE1) in Human Primary Brain Cultures and Is Reduced in Brain Tissue Specimens of Alzheimer Disease Subjects. J. Biol. Chem. 2014, 289, 5184-5198. [CrossRef]

70. Zong, Y.; Wang, H.; Dong, W.; Quan, X.; Zhu, H.; Xu, Y.; Huang, L.; Ma, C.; Qin, C. miR-29c regulates BACE1 protein expression. Brain Res. 2011, 1395, 108-115. [CrossRef] [PubMed]

71. Zhang, R.; Zhou, H.; Jiang, L.; Mao, Y.; Cui, X.; Xie, B.; Cui, D.; Wang, H.; Zhang, Q.; Xu, S. MiR-195 dependent roles of mitofusin2 in the mitochondrial dysfunction of hippocampal neurons in SAMP8 mice. Brain Res. 2016, 1652, 135-143. [CrossRef]

72. Stutzmann, G.E. Calcium Dysregulation, IP3 Signaling, and Alzheimer's Disease. Neuroscientist 2005, 11, 110-115. [CrossRef] [PubMed]

73. Chang, J.R.; Ghafouri, M.; Mukerjee, R.; Bagashev, A.; Chabrashvili, T.; Sawaya, B.E. Role of p53 in Neurodegenerative Diseases. Neurodegener. Dis. 2012, 9, 68-80. [CrossRef] [PubMed]

74. Zhang, G.-L.; Zhang, X.; Wang, X.-M.; Li, J.-P. Towards Understanding the Roles of Heparan Sulfate Proteoglycans in Alzheimer's Disease. BioMed Res. Int. 2014, 2014, 516028. [CrossRef] [PubMed]

75. Lehrer, S. Glioma and Alzheimer's Disease. J. Alzheimer's Dis. Rep. 2018, 2, 213-218. [CrossRef]

76. Penzes, P.; VanLeeuwen, J.-E. Impaired regulation of synaptic actin cytoskeleton in Alzheimer's disease. Brain Res. Rev. 2011, 67, 184-192. [CrossRef] [PubMed]

77. Vasco, V.R.L. The Phosphoinositide Signal Transduction Pathway in the Pathogenesis of Alzheimer's Disease. Curr. Alzheimer Res. 2018, 15, 355-362. [CrossRef]

78. Greene, C.; Campbell, M. Tight junction modulation of the blood brain barrier: CNS delivery of small molecules. Tissue Barriers 2016, 4, e1138017. [CrossRef]

79. Berezin, V.; Walmod, P.S.; Filippov, M.; Dityatev, A. Targeting of ECM molecules and their metabolizing enzymes and receptors for the treatment of CNS diseases. Prog. Brain Res. 2014, 214, 353-388. [CrossRef] [PubMed]

80. Zhang, T.; Han, Y.; Wang, J.; Hou, D.; Deng, H.; Deng, Y.L.; Song, Z. Comparative Epidemiological Investigation of Alzheimer's Disease and Colorectal Cancer: The Possible Role of Gastrointestinal Conditions in the Pathogenesis of AD. Front. Aging Neurosci. 2018, 10, 176. [CrossRef] [PubMed]

81. Caltagarone, J.; Jing, Z.; Bowser, R. Focal adhesions regulate A $\beta$ signaling and cell death in Alzheimer's disease. Biochim. Biophys. Acta (BBA)—Mol. Basis Dis. 2007, 1772, 438-445. [CrossRef] [PubMed]

82. Jayaraman, A.; Pike, C.J. Alzheimer's Disease and Type 2 Diabetes: Multiple Mechanisms Contribute to Interactions. Curr. Diabetes Rep. 2014, 14, 476. [CrossRef] [PubMed]

83. Maiese, K. Forkhead Transcription Factors: Formulating a FOXO Target for Cognitive Loss. Curr. Neurovasc. Res. 2018, 14, 415-420. [CrossRef]

84. Martínez, M.; Fernández, E.; Frank, A.; Guaza, C.; de la Fuente, M.; Hernanz, A. Increased cerebrospinal fluid cAMP levels in Alzheimer's disease. Brain Res. 1999, 846, 265-267. [CrossRef]

85. Haase, N.; Herse, F.; Spallek, B.; Haase, H.; Morano, I.; Qadri, F.; Szijártó, I.A.; Rohm, I.; Yilmaz, A.; Warrington, J.P.; et al. Amyloid- Peptides Activate 1-Adrenergic Cardiovascular Receptors. Hypertension 2013, 62, 966-972. [CrossRef]

86. Sevush, S.; Jy, W.; Horstman, L.L.; Mao, W.-W.; Kolodny, L.; Ahn, Y.S. Platelet Activation in Alzheimer Disease. Arch. Neurol. 1998, 55, 530-536. [CrossRef] [PubMed]

87. Plácido, A.I.; Pereira, C.M.F.; Duarte, A.I.; Candeias, E.; Correia, S.C.; Santos, R.X.; Carvalho, C.; Cardoso, S.; Oliveira, C.R.; Moreira, P.I. The role of endoplasmic reticulum in amyloid precursor protein processing and trafficking: Implications for Alzheimer's disease. Biochim. Biophys. Acta (BBA)—Mol. Basis Dis. 2014, 1842, 1444-1453. [CrossRef] [PubMed]

88. Mielke, M.M.; Lyketsos, C.G. Alterations of the Sphingolipid Pathway in Alzheimer's Disease: New Biomarkers and Treatment Targets? NeuroMol. Med. 2010, 12, 331-340. [CrossRef] [PubMed]

89. Akasaka-Manya, K.; Manya, H. The Role of APP O-Glycosylation in Alzheimer's Disease. Biomolecules 2020, 10, 1569. [CrossRef] [PubMed]

90. Zhu, X.; Lee, H.-G.; Raina, A.K.; Perry, G.; Smith, M.A. The Role of Mitogen-Activated Protein Kinase Pathways in Alzheimer's Disease. Neurosignals 2002, 11, 270-281. [CrossRef] [PubMed] 
91. Palomer, E.; Buechler, J.; Salinas, P.C. Wnt Signaling Deregulation in the Aging and Alzheimer's Brain. Front. Cell. Neurosci. 2019, 13, 227. [CrossRef] [PubMed]

92. McKay, E.C.; Beck, J.S.; Khoo, S.K.; Dykema, K.J.; Cottingham, S.L.; Winn, E.M.; Paulson, H.L.; Lieberman, A.P.; Counts, E.S. Peri-Infarct Upregulation of the Oxytocin Receptor in Vascular Dementia. J. Neuropathol. Exp. Neurol. 2019, 78, 436-452. [CrossRef] [PubMed]

93. Malik, M.; Chiles, J.; Xi, H.S.; Medway, C.; Simpson, J.F.; Potluri, S.; Howard, D.S.; Liang, Y.; Paumi, C.M.; Mukherjee, S.; et al. Genetics of CD33 in Alzheimer's disease and acute myeloid leukemia. Hum. Mol. Genet. 2015, 24, 3557-3570. [CrossRef]

94. Oddo, S. The role of mTOR signaling in Alzheimer disease. Front. Biosci. 2012, 4, 941-952. [CrossRef]

95. Angeli, S.; Kousiappa, I.; Stavrou, M.; Sargiannidou, I.; Georgiou, E.; Papacostas, S.S.; Kleopa, K.A. Altered Expression of Glial Gap Junction Proteins Cx43, Cx30, and Cx47 in the 5XFAD Model of Alzheimer's Disease. Front. Neurosci. 2020, 14, 582934. [CrossRef]

96. Woo, R.-S.; Lee, J.-H.; Yu, H.-N.; Song, D.-Y.; Baik, T.-K. Expression of ErbB4 in the neurons of Alzheimer's disease brain and APP/PS1 mice, a model of Alzheimer's disease. Anat. Cell Biol. 2011, 44, 116-127. [CrossRef] [PubMed]

97. Curtis, D.; Bandyopadhyay, S. Mini-review: Role of the PI3K/Akt pathway and tyrosine phosphatases in Alzheimer's disease susceptibility. Ann. Hum. Genet. 2020, 85, 1-6. [CrossRef] [PubMed]

98. Monsonego, A.; Nemirovsky, A.; Harpaz, I. CD4 T cells in immunity and immunotherapy of Alzheimer's disease. Immunology 2013, 139, 438-446. [CrossRef] [PubMed]

99. Watson, J.J.; Dawbarn, D. The Neurotrophins and Their Role in Alzheimers Disease. Curr. Neuropharmacol. 2011, 9, 559-573. [CrossRef]

100. Bernhardi, R.E.; Ecornejo, F.; Parada, G.E.; Eeugenin, J. Role of TGF $\beta$ signaling in the pathogenesis of Alzheimer's disease. Front. Cell. Neurosci. 2015, 9, 426. [CrossRef] [PubMed]

101. Uddin, S.; Rahman, M.; Jakaria, M.S.; Rahman, S.; Hossain, S.; Islam, A.; Ahmed, M.; Mathew, B.; Omar, U.M.; Barreto, G.E.; et al. Estrogen Signaling in Alzheimer's Disease: Molecular Insights and Therapeutic Targets for Alzheimer's Dementia. Mol. Neurobiol. 2020, 57, 2654-2670. [CrossRef]

102. Choi, H.G.; Soh, J.S.; Lim, J.S.; Sim, S.Y.; Lee, S.W. Association between dementia and hepatitis B and C virus infection. Medicine 2021, 100, e26476. [CrossRef] [PubMed]

103. Zhang, L.; Qi, Z.; Li, J.; Li, M.; Du, X.; Wang, S.; Zhou, G.; Xu, B.; Liu, W.; Xi, S.; et al. Roles and Mechanisms of Axon-Guidance Molecules in Alzheimer's Disease. Mol. Neurobiol. 2021, 58, 3290-3307. [CrossRef] [PubMed]

104. Yamazaki, Y.; Shinohara, M.; Shinohara, M.; Yamazaki, A.; Murray, M.; Liesinger, A.M.; Heckman, M.G.; Lesser, E.R.; Parisi, E.J.; Petersen, R.C.; et al. Selective loss of cortical endothelial tight junction proteins during Alzheimer's disease progression. Brain 2019, 142, 1077-1092. [CrossRef] [PubMed]

105. Hong, C.; Jeong, B.; Park, H.J.; Chung, J.Y.; Lee, J.E.; Kim, J.; Shin, Y.-C.; So, I. TRP Channels as Emerging Therapeutic Targets for Neurodegenerative Diseases. Front. Physiol. 2020, 11, 238. [CrossRef]

106. Kirouac, L.; Rajic, A.J.; Cribbs, D.H.; Padmanabhan, J. Activation of Ras-ERK Signaling and GSK-3 by Amyloid Precursor Protein and Amyloid Beta Facilitates Neurodegeneration in Alzheimer's Disease. ENeuro 2017, 4. [CrossRef] [PubMed]

107. Huh, S.; Baek, S.-J.; Lee, K.-H.; Whitcomb, D.J.; Jo, J.; Choi, S.-M.; Kim, N.H.; Park, M.-S.; Lee, K.H.; Kim, B.C. The reemergence of long-term potentiation in aged Alzheimer's disease mouse model. Sci. Rep. 2016, 6, 29152. [CrossRef] [PubMed]

108. Nixon, R.A. Endosome function and dysfunction in Alzheimer's disease and other neurodegenerative diseases. Neurobiol. Aging 2005, 26, 373-382. [CrossRef]

109. Nguyen, H.D.; Yu, B.P.; Hoang, N.H.M.; Jo, W.H.; Chung, H.Y.; Kim, M.-S. Prolactin and its altered action in Alzheimer's disease and Parkinson's disease. Neuroendocrinology 2021. [CrossRef]

110. Wang, X.; Zimmermann, H.R.; Ma, T. Therapeutic Potential of AMP-Activated Protein Kinase in Alzheimer's Disease. J. Alzheimer's Dis. 2019, 68, 33-38. [CrossRef]

111. Sanders, O.; Rajagopal, L. Phosphodiesterase Inhibitors for Alzheimer's Disease: A Systematic Review of Clinical Trials and Epidemiology with a Mechanistic Rationale. J. Alzheimer's Dis. Rep. 2020, 4, 185-215. [CrossRef] [PubMed]

112. Gabbouj, S.; Ryhänen, S.; Marttinen, M.; Wittrahm, R.; Takalo, M.; Kemppainen, S.; Martiskainen, H.; Tanila, H.; Haapasalo, A.; Hiltunen, M.; et al. Altered Insulin Signaling in Alzheimer's Disease Brain-Special Emphasis on PI3K-Akt Pathway. Front. Neurosci. 2019, 13, 629. [CrossRef]

113. Irwin, M.; Tare, M.; Singh, A.; Puli, O.R.; Gogia, N.; Riccetti, M.; Deshpande, P.; Kango-Singh, M.; Singh, A. A Positive Feedback Loop of Hippo- and c-Jun-Amino-Terminal Kinase Signaling Pathways Regulates Amyloid-Beta-Mediated Neurodegeneration. Front. Cell Dev. Biol. 2020, 8, 117. [CrossRef] [PubMed]

114. Park, Y.H.; Hodges, A.; Risacher, S.L.; Lin, K.; Jang, J.-W.; Ahn, S.; Kim, S.; Lovestone, S.; Simmons, A.; Weiner, M.W.; et al. Dysregulated Fc gamma receptor-mediated phagocytosis pathway in Alzheimer's disease: Network-based gene expression analysis. Neurobiol. Aging 2019, 88, 24-32. [CrossRef] [PubMed]

115. Maillet, M.; Robert, S.J.; Cacquevel, M.; Gastineau, M.; Vivien, D.; Bertoglio, J.; Zugaza, J.L.; Fischmeister, R.; Lezoualc'h, F. Crosstalk between Rap1 and Rac regulates secretion of sAPP $\alpha$. Nature 2003, 5, 633-639. [CrossRef]

116. Vogrinc, D.; Goričar, K.; Kunej, T.; Dolžan, V. Systematic Search for Novel Circulating Biomarkers Associated with Extracellular Vesicles in Alzheimer's Disease: Combining Literature Screening and Database Mining Approaches. J. Pers. Med. 2021, 11, 946. [CrossRef] [PubMed]

117. Das, B.; Yan, R. Role of BACE1 in Alzheimer's synaptic function. Transl. Neurodegener. 2017, 6, 23. [CrossRef] 
118. O’Brien, R.J.; Wong, P.C. Amyloid Precursor Protein Processing and Alzheimer's Disease. Annu. Rev. Neurosci. $2011,34,185-204$. [CrossRef]

119. Kaether, C.; Haass, C.; Steiner, H. Assembly, Trafficking and Function of $\gamma$-Secretase. Neurodegener. Dis. 2006, 3, 275-283. [CrossRef]

120. Yoon, H.; Shin, S.-H.; Shin, D.H.; Chun, Y.-S.; Park, J.-W. Differential roles of Sirt1 in HIF-1 $\alpha$ and HIF-2 $\alpha$ mediated hypoxic responses. Biochem. Biophys. Res. Commun. 2014, 444, 36-43. [CrossRef]

121. Kleszka, K.; Leu, T.; Quinting, T.; Jastrow, H.; Pechlivanis, S.; Fandrey, J.; Schreiber, T. Hypoxia-inducible factor-2 $\alpha$ is crucial for proper brain development. Sci. Rep. 2020, 10, 19146. [CrossRef]

122. Elalla, R.; Edonmez, G. The role of sirtuins in Alzheimer's disease. Front. Aging Neurosci. 2013, 5, 16. [CrossRef]

123. Citron, B.A.; Dennis, J.S.; Zeitlin, R.S.; Echeverria, V. Transcription factor Sp1 dysregulation in Alzheimer's disease. J. Neurosci. Res. 2008, 86, 2499-2504. [CrossRef]

124. Knafo, S.; Sánchez-Puelles, C.; Palomer, E.; Delgado, I.; Draffin, E.J.; Mingo, J.; Wahle, T.; Kaleka, K.; Mou, L.; Pereda-Perez, I.; et al. PTEN recruitment controls synaptic and cognitive function in Alzheimer's models. Nat. Neurosci. 2016, 19, 443-453. [CrossRef]

125. Frere, S.; Slutsky, I. Targeting PTEN interactions for Alzheimer's disease. Nat. Neurosci. 2016, 19, 416-418. [CrossRef]

126. Chen, D.; Hao, S.; Xu, J. Revisiting the Relationship between Alzheimer's Disease and Cancer with a circRNA Perspective. Front. Cell Dev. Biol. 2021, 9, 647197. [CrossRef]

127. Ou, S.-M.; Lee, Y.-J.; Hu, Y.-W.; Liu, C.-J.; Chen, T.-J.; Fuh, J.-L.; Wang, S.-J. Does Alzheimer's Disease Protect against Cancers? A Nationwide Population-Based Study. Neuroepidemiology 2013, 40, 42-49. [CrossRef] [PubMed]

128. Driver, A.J.; Beiser, A.; Au, R.; Kreger, E.B.; Splansky, G.L.; Kurth, T.; Kiel, D.; Lu, K.P.; Seshadri, S.; Wolf, A.P. Inverse association between cancer and Alzheimer's disease: Results from the Framingham Heart Study. BMJ 2012, 344, e1442. [CrossRef] [PubMed]

129. Liu, T.; Ren, D.; Zhu, X.; Yin, Z.; Jin, G.; Zhao, Z.; Robinson, D.; Li, X.; Wong, K.; Cui, K.; et al. Transcriptional signaling pathways inversely regulated in Alzheimer's disease and glioblastoma multiform. Sci. Rep. 2013, 3, 3467. [CrossRef]

130. Musicco, M.; Adorni, F.; Di Santo, S.; Prinelli, F.; Pettenati, C.; Caltagirone, C.; Palmer, K.; Russo, A. Inverse occurrence of cancer and Alzheimer disease: A population-based incidence study. Neurology 2013, 81, 322-328. [CrossRef] [PubMed]

131. Calabrò, M.; Rinaldi, C.; Santoro, G.; Crisafulli, C. The biological pathways of Alzheimer disease: A review. AIMS Neurosci. 2021, 8, 86-132. [CrossRef] [PubMed]

132. Caruana, E.J.; Roman, M.; Hernández-Sánchez, J.; Solli, P. Longitudinal studies. J. Thorac. Dis. 2015, 7, E537. [CrossRef] [PubMed]

133. Wang, Z.; Qin, W.; Wei, C.; Tang, Y.; Zhao, L.; Jin, H.; Li, Y.; Wang, Q.; Luan, X.; He, J.; et al. The microRNA-1908 up-regulation in the peripheral blood cells impairs amyloid clearance by targeting ApoE. Int. J. Geriatr. Psychiatry 2018, 33, 980-986. [CrossRef]

134. Giri, M.; Lü, Y.; Zhang, M. Genes associated with Alzheimer's disease: An overview and current status. Clin. Interv. Aging 2016, 11, 665-681. [CrossRef]

135. Deng, H.; Lv, L.; Li, Y.; Zhang, C.; Meng, F.; Pu, Y.; Xiao, J.; Qian, L.; Zhao, W.; Liu, Q.; et al. The miR-193a-3p regulated PSEN1 gene suppresses the multi-chemoresistance of bladder cancer. Biochim. Biophys. Acta (BBA)—Mol. Basis Dis. 2014, 1852, 520-528. [CrossRef] [PubMed]

136. Robinson, R.A.S.; Amin, B.; Guest, P.C. Multiplexing Biomarker Methods, Proteomics and Considerations for Alzheimer's Disease. Proteom. Methods Neuropsychiatry Res. 2017, 974, 21-48. [CrossRef]

137. Maoz, R.; Garfinkel, B.P.; Soreq, H. Alzheimer's Disease and ncRNAs. Neuroepigenom. Aging Dis. 2017, 978, 337-361. [CrossRef]

138. Lugli, G.; Cohen, A.M.; Bennett, D.A.; Shah, R.; Fields, C.; Hernandez, A.G.; Smalheiser, N.R. Plasma Exosomal miRNAs in Persons with and without Alzheimer Disease: Altered Expression and Prospects for Biomarkers. PLoS ONE 2015, 10, e0139233. [CrossRef]

139. Leidinger, P.; Backes, C.; Deutscher, S.; Schmitt, K.; Mueller, S.C.; Frese, K.; Haas, J.; Ruprecht, K.; Paul, F.; Stähler, C.; et al. A blood based 12-miRNA signature of Alzheimer disease patients. Genome Biol. 2013, 14, R78. [CrossRef]

140. Zetterberg, H.; Burnham, S.C. Blood-based molecular biomarkers for Alzheimer's disease. Mol. Brain 2019, 12, 26. [CrossRef]

141. Zhao, Y.; Bhattacharjee, S.; Jones, B.M.; Dua, P.; Alexandrov, P.N.; Hill, J.M.; Lukiw, W.J. Regulation of TREM2 expression by an NF-kB-sensitive miRNA-34a. NeuroReport 2013, 24, 318-323. [CrossRef] [PubMed] 